\title{
UNDERSTANDING THE LOST CONTRACTS AND IMPLEMENTATION OF MUDHARABAH BANKING SHARIA: FROM THE PERSPECTIVE OF CONTEMPORARY ISLAMIC ACADEMICS AND PRACTITIONERS
}

\author{
Mahmudah Nufidatul, Djamhuri Ali, Purwanti Lilik \\ University of Brawijaya, Malang, Indonesia \\ *E-mail: nufidatulmahmudah@yahoo.com
}

\begin{abstract}
The current research aims to understand the contract loss and the mudharabah implementation in Indonesian Islamic banking (Sharia banking) based on the perspective of contemporary Islamic academics and practitioners. This study applies the transcendental phenomenological interpretive paradigm data analysis technique coined by Edmund Husserl. The conclusion theoretically implies the meaning of mudharabah is a cooperation based on the principle of help between the customer (mudharib) and the capital owner (shahibul-maal), according to contemporary Islamic academics. On the other hand, the contract is considered very risky, one of which is that capital owners must lose $100 \%$ of their capital if the customer's business suffers losses. Besides, according to contemporary Islamic practitioners, the majority of Indonesians have a low value of trust which ultimately changes the mudharabah as principle of helping to be the principle of prudence. Mudharabah is also a cooperation contract that is less attractive to customers. Moreover, the bank requirements given to customers is quite difficult to be fulfilled by the customers, aligned with the magnitude of the risk borne by the bank in mudharabah financing. As a result, if Islamic banking practices minimize or even discards mudharabah contracts with the profit-sharing regulation based on the principle of prudence, Islamic banks will lose their identity as "profitsharing" banks. Therefore, Islamic banks should continue to apply mudharabah contracts by demanding an accounting process as the accountability of customers as mudharib to Islamic banking as shahibul-maal.
\end{abstract}

\section{KEY WORDS}

Mudharabah, contemporary Islamic academics, contemporary Islamic practitioners, banking, Sharia, Indonesia.

The development and growth of Islamic banking in Indonesia is not only driven by the passing of Undang-Undang (law) number 10 of 1998 remarkably known as Undang-Undang number 7 of 1992 which allows banks to undergo a dual banking system (Arif, Haribowo, \& Suherlan, 2018). This development is correspondingly desired by Muslims as the majority of Indonesian' population to avoid the usage of bank interest in conventional banking (Fasa, 2013). Mudharabah, a profit-sharing mechanism in Sharia banking core products is expected to be an alternative to replace usury interest in conventional banking (Muhamad, 2014). Unlike the characteristics of interest forcing the results to always be profitable, the profitsharing system can be positive or negative depending on the profit or loss generated by customers in the real sector who are assisted by using mudharabah financing that is carried out honestly (Bidabad, 2014). In addition, to helping people free from usury, mudharabah is demanded to be able to support economic growth (Huda, 2012). This is reflected in the mudharabah financing mechanism that receives funds from the surplus person, afterward distributes them through financing to deficit persons. The surplus person who cannot manage their assets in the business and deficit person who have business skill but do not have the capital are able to do profit-sharing cooperation through mudharabah financing (Suryanto, 2015). The surplus person turns as shahibul-maal who provides $100 \%$ capital, while the deficit person acts as mudharib or business manager (Ahmed, 2014). 
In fact, the increasing number of Islamic banking is not accompanied by the increasing number of mudharabah financing in accordance with the spirit of the Islamic banking system. The low proportion of mudharabah financing in Islamic banking is shown in the data:

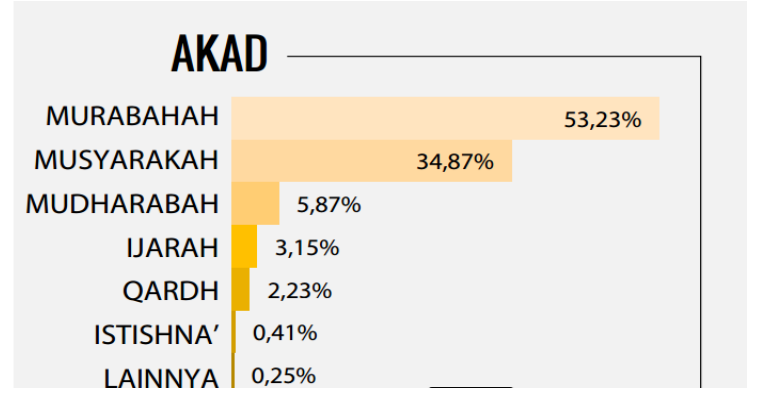

Figure 1 - Sharia Banking Financing Composition (Source: Otoritas Jasa Keuangan, 2017)

Based on the figure 1, the proportion of debt-based murabahah financing is the most popular financing, which is around $52.23 \%$, while profit-sharing-based mudharabah which is the core product of Islamic banking is only about $5.87 \%$ (Otoritas Jasa Keuangan, 2017). It means that Islamic banking practices have not fully reflected the Islamic economy. In fact, mudharabah financing is the primary Islamic financing (Dewi \& Astari, 2018). Basically, Islamic economic principles place more emphasis on the real sector compared to the financial sector, in other words, Islamic banking should focus on mudharabah capital-based financing rather than debt-based murabahah products.

The reason for the proportion of mudharabah financing shifts very low is that there are many risks in it. Four main risks of mudharabah financing include high investment risk, difficulties in selecting customers, low levels of trust, and lack of security levels of capital (Abdul-rahman \& Nor, 2017). However, there are two risks of mudharabah financing for shahibul-maal: 1) in terms of mudharib behavior such as the occurrence of an error, negligence or taqshir, failure, breach of agreement and misuse; and 2) in terms of business risk that cannot be predicted (Herijanto, 2016). Besides, the lack of application of Islamic values in the practice of mudharabah financing is the major reason why mudharabah is difficult to be applied (Shaikh, 2011). The emergence of the risks in mudharabah financing are: high non-performing financing caused by irregularities in the use of funds by customers that are not under the agreement at the beginning of the contract; changing in management of customer management; and the existence of dishonesty by the customer when reporting the financial condition of the customer's business (Indrianawati, Lailah, \& Karina, 2015).

Another research shows that there are two problems in mudharabah contracts at Baitul Maal Usaha Gabungan Terpadu Sidogiri Cabang Malang. Firstly, the financial institution does not know for certain the character of the prospective customer. The second problem is that there are mudharabah financing customers who does not use funds under the agreement (Multifiah, Manzilati, \& Hurriati, 2015). Based on the study, it can be concluded that the risk of mudharabah is largely due to the behavior of customers who are less trustful and professional in utilizing capital provided by Islamic banking or shahibul-maal.

These facts reveal that the current mudharabah financing works less than what is supposed to compared to mudharabah financing in the era of Prophet Muhammad Shalallahualaihiwasallam. Among those who carry out mudharabah activities are the Prophet Muhammad Shalallahualaihiwasallam and Khadijah, the mudharib and the shaibul- maal (Antonio, 2010: 16). Khadija was interested in the nature of the trust, honesty and wisdom of the Prophet Muhammad Shallallahualaihiwasallam in commerce. This illustrates that the mudharabah trade cooperation that is happening today is very different from the times exemplified by the Prophet Muhammad. As a mudharib, he worked professionally and reliably in managing his mudharabah funds, so that in addition to being successful in his trading business, he also made his shahibul-maal share more than what was agreed at the beginning. 


\section{METHODS OF RESEARCH}

In this study, the researchers wanted to obtain data regarding the loss of contracts and implementation of mudharabah based on knowledge from contemporary Islamic scholars and practitioners. Following by the objectives of the study, it used non-positive research with an interpretive paradigm. In the interpretive paradigm, methods that can be used were such as phenomenology and hermeneutics (Kamayanti, 2016: 21). Between both methods, this research was more suitable to use the phenomenology approach.

In that case, phenomenology seeks to understand how a person experiences and gives meaning to an experience (Kuswarno, 2009: 25). Kamayanti (2016: 165) mentions that accounting research that can utilize phenomenology is research that aims individual accountants' understanding of certain accounting symbols or practices. In this study, the symbol to be captured is the opinion of mudharabah financing based on the knowledge and experience of key informants. Knowledge gained from contemporary Islamic academics is a theory that should be used as a reference for mudharabah financing practices. In addition, experiences gained from contemporary Islamic practitioners are practices that occur in real life.

There are three research sites: 1) A university lecturer in Malang who teaches Fiqh Muamalah; 2) Islamic Boarding School Ustadhz (teacher) who understand the science of fiqh muamalah. The researchers chose these two sites due to the lecturers and ustadhz are needed as the informants of contemporary Islamic academics. In this study, the researchers referred to the Lecturer as Mr. A, while the ustadz referred to as Mr. B with the aim of maintaining the privacy of the informants; 3) Two syariah banking in the city of Malang. These needed informants on this site are contemporary Islamic practitioners who have been handling mudharabah financing directly. A finance marketing staff member of Bank Syariah $C$ and an Islamic Official Development Program Bank Syariah $D$ have been selected, referred to Mr. C and Mr. D. The type of interview in this research is semi-structured interview. The validity test of the data is to review the phenomenological study reports by key informants sent via WhatsApp. The analysis technique uses transcendental phenomenology with five analysis techniques consisting of noema, noesis, epoche (bracketing), intentional analysis and eidetic reduction coined by Edmund Husserl (Kamayanti, 2016: 153).

\section{RESULTS OF STUDY}

The informants in this study were two contemporary Islamic academics consisting of Mr. A and Mr. B, and two contemporary Islamic practitioners consisting of Mr. C and Mr. D.

Based on the results of the interview, according to Mr. A, the mudharabah contract is a simple cooperation contract but has high risks. Said to be simple in terms of the system because it only involves two stakeholders, a shahibul-maal, who deposit $100 \%$ of the capital with a mudharib, who manages the capital in a business. Both stakeholders have to agree on the amount of profit-sharing for the business profits received by each. Mudharabah contracts are said to be high risk because if a loss or bankrupt occurs, the shahibul-maal will automatically lose $100 \%$ of the capital. A shahibul-maal also faces the risk if the mudharib is not trustworthy. Those risks are caused by the rules in the mudharabah contract is stated that shahibul-maal only delivers the capital without interfering in the business process. In this case, the possibility of fraud by the mudharib is very possibly large. In general, the meaning of the mudharabah contract according to Mr. A is explained by the researcher in figure 2 .

Understanding the meaning of mudharabah according to Mr. B is a cooperation contract that is "profitable but not yet suitable for practice in Indonesia". Said to be a profitable collaboration when compared to the existing debt system in conventional banks. Conventional banks require customers to return the capital and interest regardless of the customer's business conditions, whether experiencing gains or losses, get a little or a lot of profit. In addition, in the Islamic banking mudharabah financing system, the paid amount by the customer depends on the customer's business conditions, if the customer's business is 
profitable, the capital return is along with the profit-sharing that he set, otherwise if there is a loss, there is no need to return the capital.

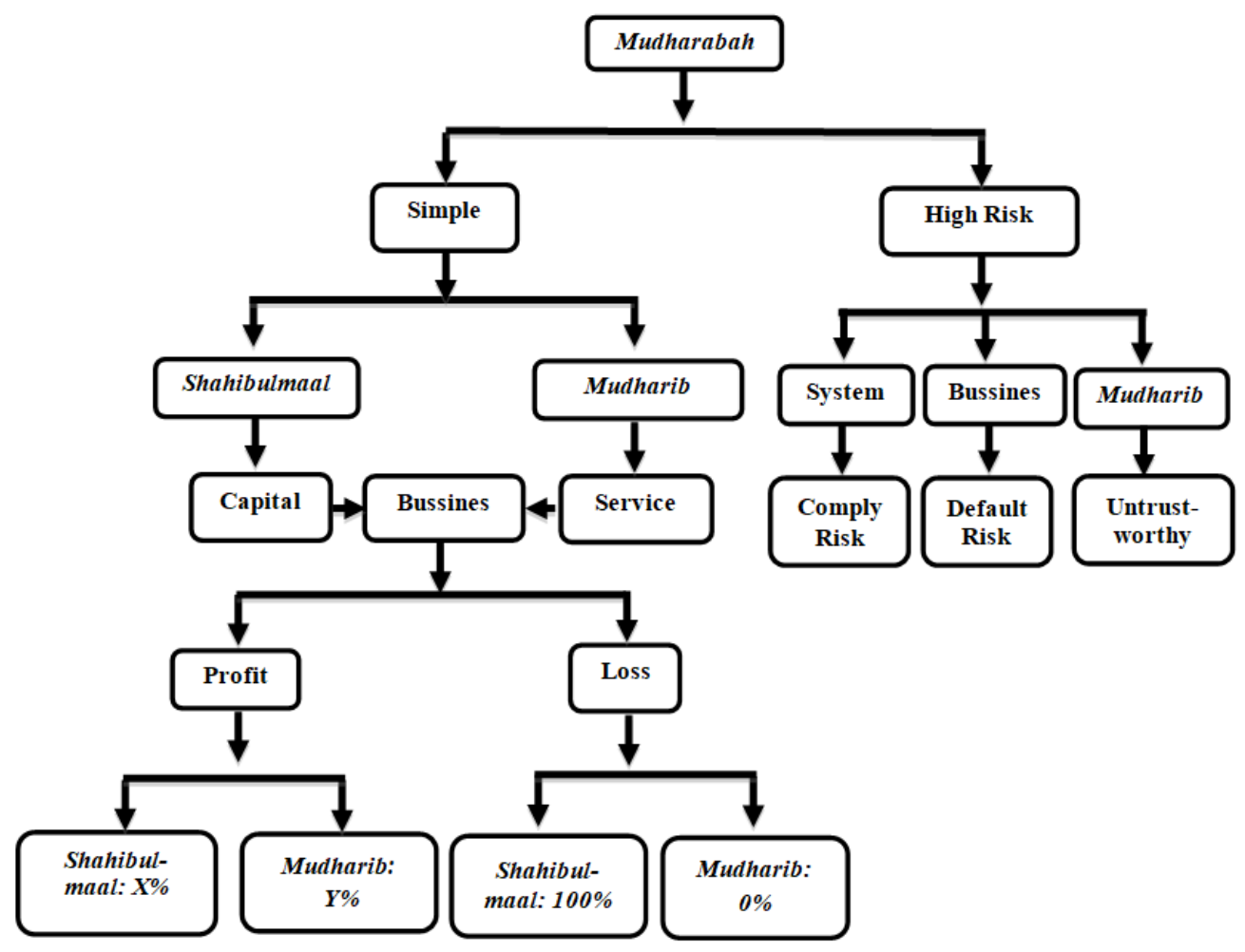

Figure 2 - Mr. A's understanding of the mudharabah contract

Due to the low-level trust of Indonesian people, Islamic bank capital owners are still reluctant to entrust their capital to customers through mudharabah financing.

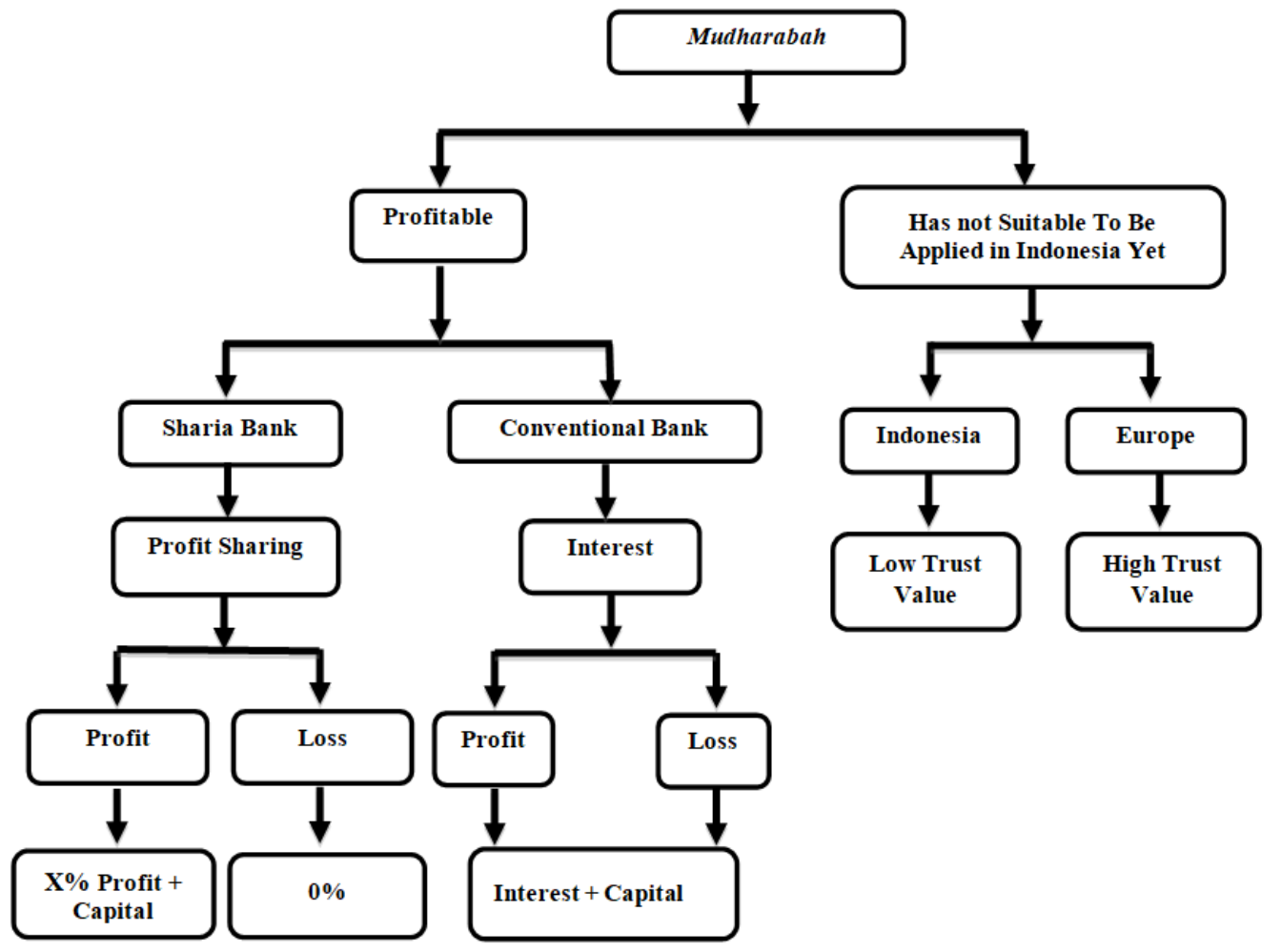

Figure 3 - The Mr. B's understanding about mudharabah contract 
Furthermore, Mr. C's opinion about mudharabah is to understand mudharabah financing as with $100 \%$ capital from the bank, so the risk faced by the bank is widely large. Therefore, Sharia Bank C deliberately minimizes the financing which finally at this time mudharabah is not suitable yet to be applied. In general, the researchers explained the meaning of mudharabah contracts according to Mr. C in the following figure:

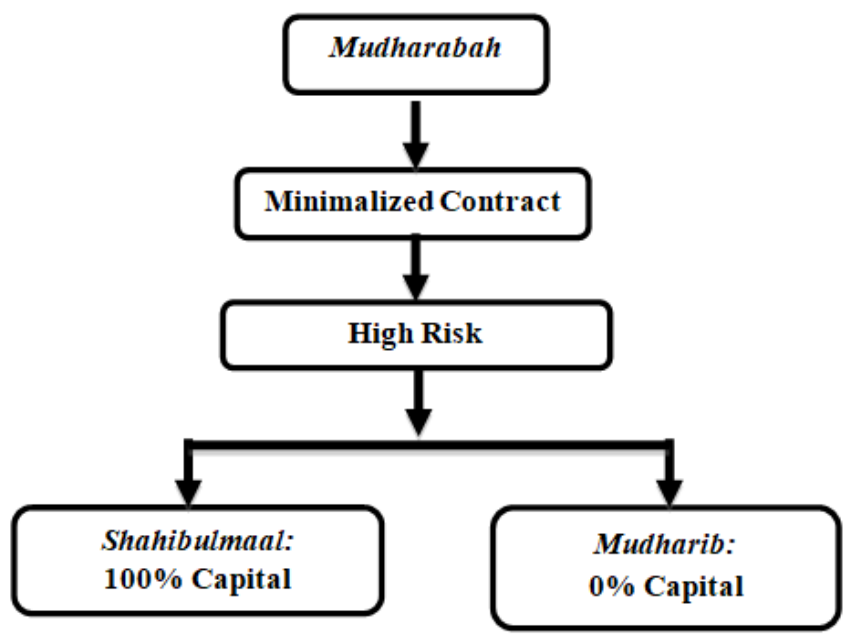

Figure 4 - The Mr. C's understanding about mudharabah

Furthermore, according to Mr. D, the mudharabah contract is a cooperation contract that is less attractive to customers. The target customer in mudharabah financing is other than people who do not have money, but he must have a guarantee of high value. The average person who needs capital for business is someone who does not have high-value assets. Customers also do not contribute capital at all, even though there are rarely customers who have no money at all. Besides, the profit-sharing regulations received by banks are greater than those received by customers, which also makes customers of Shariah Bank $D$ less interested in conducting this financing. In general, the meaning of mudharabah according to Mr. D, the researchers explain in the following figure:

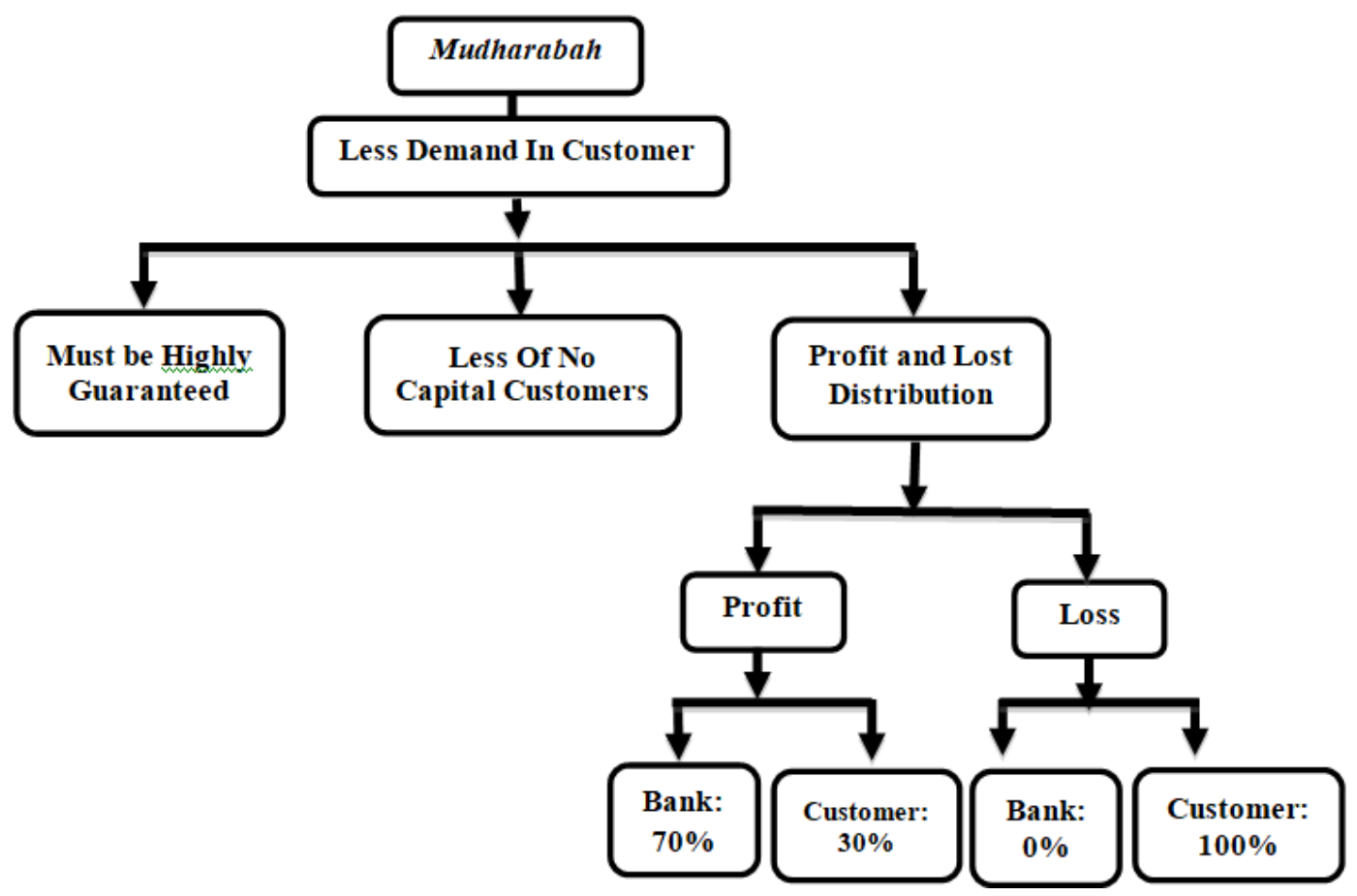

Figure 5 - The Mr. D's Understanding about Mudharabah 


\section{DISCUSSION OF RESULTS}

The researchers summarized that theoretically, the basic principle of mudharabah financing is the principle of mutual assistance. It is reflected in the basic purpose of mudharabah cooperation which acts as a bridge between people who have assets but are unable to manage them, and someone who does not have assets but able to do so. Due to the high-odds frauds, the mutual assistance turns into the principle of prudence.

The principle of mudharabah is stated in the Quran that Islam recommends the mutualhelp in Surah (Al-Mâidah, 5: 2): "...and cooperate in righteousness and piety...". The principle of mudharabah financing in Islamic banks is determined from the bank's responsibility to the deficit person. Islamic bank institutions should uphold social goals and promote Islamic values, including contributing to the social welfare of the community, promoting sustainable development projects and reducing poverty (Waluyo, 2016). In this case, banks carry out and contribute to fulfilling the capital needs, such as capital for business or capital to meet customer needs. Banks are encouraged to provide economic prosperity to long-term deficit persons such as capital distribution in mudharabah financing compared to short-term financing distribution. By providing capital in mudharabah financing, banks provide an opportunity for deficit persons to open a business that can ultimately be used as a profession and source of income in the long run. The bank's contribution was proven in a study which stated that the small community felt fully helped by mudharabah financing because it kept the community away from loan sharks, saving Muslims from the practice of usury which was clearly unclean of the law (Munir \& Wardani, 2016).

Sharia banks as an intermediary between surplus people and deficit persons amid society must be responsible to their duties not only on deficit people, but to surplus persons who keep their money in Islamic banks. The must be able to make sure that the capital is safe, even increasing profits through profit sharing. One of the strategies is by channeling their capital into relatively safe financing such as financing that promises definite benefits, so that the capital distributed is intact and even increases with the benefits. If this is wellachieved, the banks can return the capital and profit sharing to customers who save in the Islamic bank. This is evident from the popularity of murabahah financing which dominates the distribution of funds in Islamic banks, compared to mudharabah (Bahjatulloh, 2011). Owing to the fact that murabahah is the most profitable financing and has the least risk to Sharia banks. There are no restrictions on profits derived from a trade, so the Islamic banks in theory freely determine any mark-up (profits) from murabahah contracts.

Besides that, the moral hazard and lack of readiness of human resources in Sharia banking are among the factors that make the composition of distribution of funds to the public more in the form of sale and purchase financing (murâbahah), compared to equity participation (mudhârabah) (Hadi, 2015). The funding on mudharabah products is indeed considered very risky, especially for Sharia financial institutions as shahibul-maal and more lighten for mudharib (Aziz, 2014). The risk is about mudharabah rules that determine if a loss occurs in the mudharabah customer business, then the bank must lose $100 \%$ of its capital. Besides, based on research, mudharabah financing does not affect the profit of Bank Syariah Mandiri (Fadhila, 2015). This makes the bank worry, when the bank loses capital, the bank will not able to return its obligations to the surplus person because the main purpose of the surplus person saving at the bank is to make a profit. If they do not get profits or even the money deposited in the bank cannot be returned, it will affect the image of the bank in the eyes of the public. In this case, mudharabah is one of the types of cooperation that currently has constraints, because of the high-risk of prospective managers (mudharib), and the lack of readiness of human resources in Islamic banking, so that shahibul-maal / banks are reluctant to use this contract scheme (Rahayu, 2013). Those cases encourage banks to minimize or not apply mudharabah financing on the grounds of the bank's prudential principle in channeling its capital which is not bank money, but customer savings money. In this case, it can be said that Islamic banks are not ready to bear the loss which is a common thing in the pattern of business/ commercial relations, the bank seeks to remain profitable, or at least the capital returns intact (Vidada, 2015). 


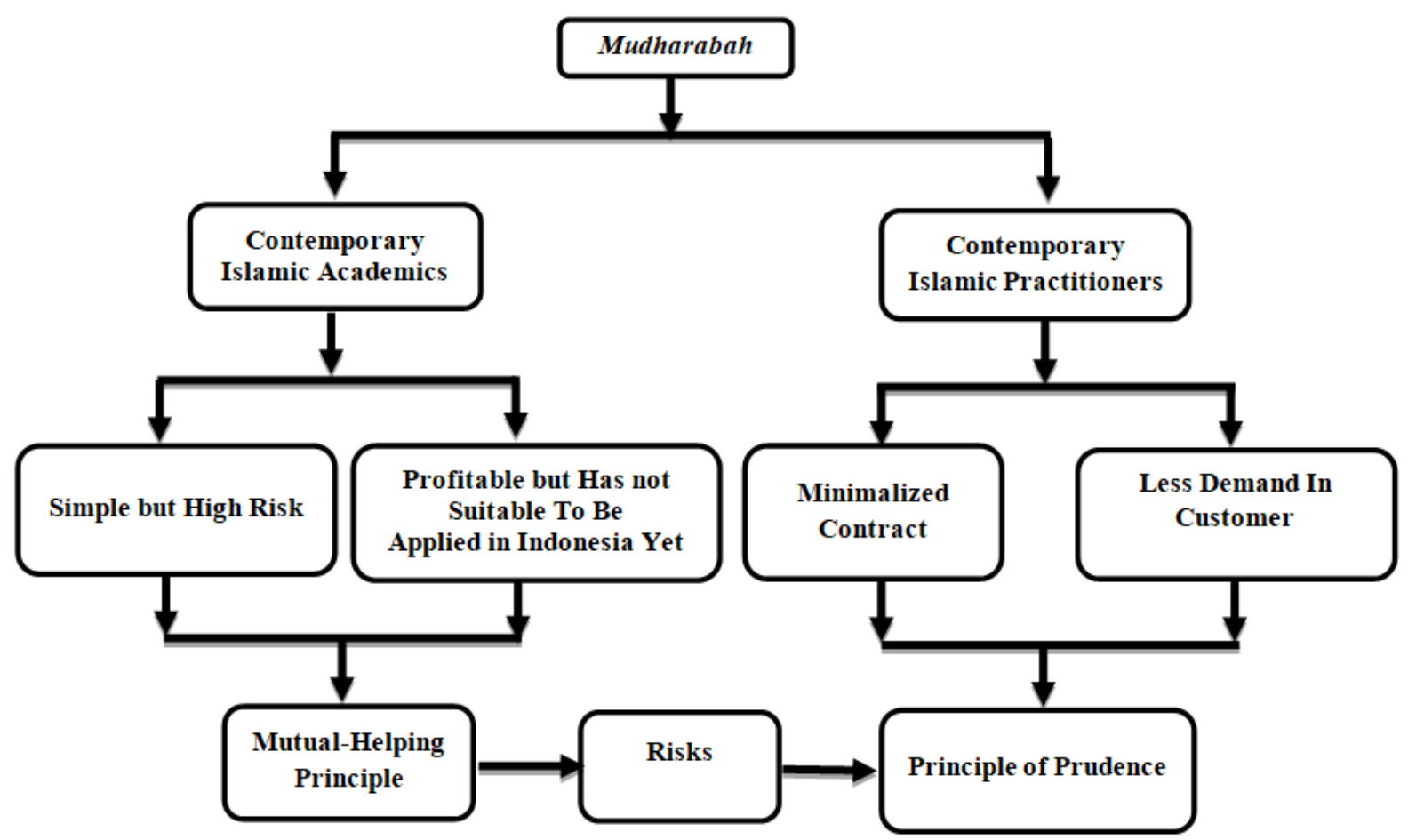

Figure 6 - Mudharabah Contract: The meeting point between the Academics and Practitioners of Contemporary Islamic Perspective's

\section{CONCLUSION}

Technically, mudharabah practices are carried out in Islamic banking, banks as shahibul-maal and customers as mudharib. According to contemporary Islamic practitioners, nowadays, the numbers of mudharabah are rarely to be found due to its high-risk. Sharia banks realize that the capital in the mudharabah is not its original capital but the customers who are saving, so the banks place it in safe financing prudently. But, Islamic banks will lose their identity as a "profit-sharing" bank if the bank does not implement mudharabah contracts. Therefore, Islamic banks should continue to develop and implement mudharabah contracts by demanding an accounting process carried out by the mudharib as their accountability to Sharia banks as shahibul-maal. The limitation of this study is that the researcher couldn't interview mudharabah customers as a consequence of no customers using mudharabah financing at the two banks. Suggestions for further researchers are expected to conduct this research in foreign Sharia banks that are more advanced.

\section{REFERENCES}

1. Abdul-rahman, A., \& Nor, S. M. (2017). Challenges of profit-and-loss sharing financing in Malaysian Islamic banking. Geografia - Malaysian Journal of Society and Space, 12(2), 39-46.

2. Ahmed, H. (2014). Islamic Banking and Shari'ah Compliance: A Product Development Perspective. Journal of Islamic Finance, 3(2), 15-29. https://doi.org/10.12816/0025102.

3. Antonio, S. (2010). Ensiklopedia Leadership \& Managemen Muhammad SAW "The Super Leader Super Manager". Jakarta: Tazkia.

4. Arif, M. N. R. A, Haribowo, I., \& Suherlan, A. (2018). Spin-off policy and efficiency in the Indonesian islamic banking industry. Banks and Bank Systems, 13(1), 1-10. https://doi.org/10.21511/bbs.13(1).2018.01.

5. Aziz, A. (2014). Manajemen Risiko Pembiayaan Mudharabah Pada Lembaga Keuangan Syariah. Al-Amwal: Jurnal Ekonomi Dan Perbankan Syari'ah, 6(1), 95-108. https://doi.org/10.24235/AMWAL.V6I1.252. 
6. Bahjatulloh, Q. M. (2011). Kajian Pembiayaan Murabahah Antara Teori dan Praktek. Muqtasid: Jurnal Ekonomi Dan Perbankan Syariah, 2(2), 281-303. https://doi.org/10.18326/muqtasid.v2i2.281-303.

7. Bidabad, B. (2014). Mudarabah Financial Sharing ( MFS ). Journal of Islamic Economics Banking and Finance, 10(1), 56-68. https://doi.org/10.12816/0025697.

8. Dewi, E. K., \& Astari, A. (2018). Peran Pembiayaan Mudharabah dalam Pengembangan Kinerja Usaha Mikro pada BMT (Baitul Maal Wat Tamwil). Law and Justice, 2(2), 113123. https://doi.org/10.23917/laj.v2i2.5142.

9. Fadhila, N. (2015). Analisis Pembiayaan Mudharabah Dan Murabahah Terhadap Laba Bank Syariah Mandiri. Riset Akuntansi Dan Bisnis, 15(1), 52-64.

10. Fasa, M. I. (2013). Tantangan Dan Strategi Perkembangan Perbankan Syariah Di Indonesia. Jurnal Ekonomi Islam, 2(1), 19-40.

11. Hadi, A. C. (2015). Problematika Pembiayaan Mudharabah di Perbankan Syariah Indonesia. Al-lqtishad: Journal of Islamic Economics, 3(2), 193-208. https://doi.org/10.15408/aiq.v3i2.2129.

12. Herijanto, H. (2016). The Mudharib's Legal Responsibility for the Business Risk in Mudharabah. Journal of Islamic Banking and Finance, 4(1), 22-32. https://doi.org/10.15640/jibf.v4n1a3.

13. Huda, A. N. (2012). The Development of Islamic Financing Scheme for SMEs in a Developing Country: The Indonesian Case. Procedia - Social and Behavioral Sciences, 52, 179-186. https://doi.org/10.1016/j.sbspro.2012.09.454.

14. Indrianawati, I., Lailah, N., \& Karina, D. (2015). Manajemen Risiko Pembiayaan Mudharabah Pada Perbankan Syariah. Journal of Innovation in Business and Economics, 6(1), 55-56. https://doi.org/10.22219/jibe.vol6.no1.55-66.

15. Kamayanti, A. 2016. Metodologi Penelitian Kualitatif Akuntansi. Pengantar Religiositas Keilmuan. Cetakan Pertama. Jakarta Selatan: Yayasan Rumah Peneleh.

16. Kuswarno, E. 2009. Fenomenologi Konsepsi, Pedoman, dan Contoh Penelitian. Bandung Widya: Padjajajaran.

17. Muhamad. 2014. Manajemen Keuangan Syari'ah: Analisis Fiqih \& Keuangan. Yogyakarta: UPP STIM YKPN.

18. Multifiah, M., Manzilati, A \& Hurriati, L. (2015). Agency Problem and Its Enforcement In Funding Mudharabah: Study of Baitul Maal wa Tamwil Usaha Gabungan Terpadu Sidogiri, Malang Branch. International Journal of Social and Local Economic Governance, 1(1), 52-60. https://doi.org/10.21776/ub.ijleg.2015.001.01.7.

19. Munir, M., \& Wardani, M. D. (2013). Peran Pembiayaan Bagi Hasil Mudharabah Dalam Pengembangan Usaha Nasabah. El-Dinar, 1(1), 67-84.

20. Otoritas Jasa Keuangan. (2017). Snapshot Perkembangan Perbankan Syariah 2017.

21. Rahayu, E. J. (2013). Mitigasi Resiko Akad Pembiayaan Mudharabah pada Perbankan Syariah. Muqtasid: Jurnal Ekonomi Dan Perbankan Syariah, 4(1), 55-73. https://doi.org/10.18326/muqtasid.v4i1.

22. Shaikh, S. A. (2011). Critical Analysis of Islamic Equity Financing. Journal of Islamic Banking \& Finance.

23. Suryanto, T. (2015). Implementation of fair value accounting on agency problem contract Mudharaba in Islamic Finance. International Journal of Economic Perspectives, 9(4), 94102.

24. Vidada, I. A. (2015). Tinjauan Praktek Mudharabah Perbankan Syariah Di Indonesia. Moneter, II(1), 44-55.

25. Waluyo, B. (2016). Implementasi Pembiayaan Mudharabah Pada Bank Syariah untuk Merealisasikan Tujuan Ekonomi Islam. Jurnal Ekonomi Dan Bisnis Islam, 2(2), 186-204. 